\title{
Klass i det tjugoförsta århundradet
}

\section{Göran Therborn}

SAMMANDRAG: Om 1900-talet i samhällshistorisk mening var arbetarklassens århundrade verkar allt fler mena att 2000-talet kommer att bli den globala medelklassens tidsålder. För liberaler framstår framväxten av nya medelklasser i utvecklingsländerna som en garant för ekonomisk tillväxt och en demokratisk utveckling. Men är det så enkelt? Vad utmärker egentligen denna "nya medelklass", hur ser den ut och vad strävar den efter? Och hur ska vi förstå medelklassens position i förhållande till de heterogena, ofantliga folkliga klasser som utgör världens underklass, eller till den politiskt marginaliserade men numerärt fortfarande betydande, och växande, arbetarklassen, som nu i allt högre grad återfinns i samma utvecklingsländer där den nya medelklassen bryter fram? Detta är utgångspunkten för Göran Therborns artikel, en välbehövlig översikt över vårt unga sekels nya klasslandskap. I en uppföljande artikel, ”Nya massor? Motståndets sociala grundvalar" (även den publicerad i detta nummer av Arkiv), analyserar Therborn de sociala krafter som skulle kunna utmana dagens globala kapitalism.

NYCKELORD: klass; medelklass; arbetarklass; folkliga klasser; underklass; arbetarrörelse; sociala rörelser; konsumism; avindustrialisering; global kapitalism.

PUBLICERINGSHISTORIK: Översättning av en, av författaren, något reviderad och utvidgad version av artikeln "Class in the 2Ist Century" i New Left Review, nr 78 (20I2).

GÖRAN THERBORN är professor emeritus i sociologi vid University of Cambridge och affilierad professor vid Linnéuniversitetet.

E-POSTADRESS: gt274@cam.ac.uk

FÖRSLAG PÅ KÄLLANGIVELSE:

Therborn, Göran (20I4) "Klass i det tjugoförsta århundradet”, i Arkiv. Tidskrift för samhällsanalys, nr 3, s. 67-97.

DoI: http://dx.doi.org/IO.I3068/2000-6217.3.3

(C) original: Göran Therborn/New Left Review 2012

(C) svensk version: Göran Therborn/Arkiv förlag \& tidskrift 2014

(publicerad 22 december 20I4)

Artikeln distribueras enligt en upphovsrättslicens från Creative Commons:

Erkännande-Ickekommersiell-IngaBearbetningar 3.0 Unported, som medger fri ickekommersiell användning och spridning i oförändrat skick så länge källan anges. 
Arkiv. Tidskrift för samhällsanalys är en sakkunniggranskad vetenskaplig tidskrift för samhällsvetenskap och historia. Samtliga artiklar publiceras fritt tillgängliga på:

www.tidskriftenarkiv.se

(beständig länk, DoI: http://dx.doi.org/IO.I3068/2000-62I7)

Den här artikeln finns tillgänglig i följande format:

PDF \& HTML: via beständig länk, DOI: http://dx.doi.org/IO.I3068/2000-62I7.3.3

EPUB: ingår i e-boksutgåva av numret, ISBN: 978 9I 79242657

TRYCK: ingår i bokutgåva av numret, ISBN: 978 9I 79242664

Grafisk utformning och sidnumrering är identisk i pdf och tryck.

Samtliga artiklar i nr 3 (20I4) nås via beständig länk, DOI: http://dx.doi.org/I0.13068/2000-6217.3

Arkiv. Tidskrift för sambällsanalys ISSN: 2000-62I7 (för elektronisk resurs)

ISSN: 2000-6225 (för tryckta nummer)

ges ut av

Stiftelsen Arkiv för främjande och spridning av samhällsvetenskaplig och historisk forskning

genom

Arkiv förlag \& tidskrift

Box 1559

SE-22I OI Lund

ВESÖK: L Gråbrödersg 3 c, ipg

TEL: O46-I3 3920

ARKIV FÖRLAG: arkiv@arkiv.nu·www.arkiv.nu

TIDSKRIFTEN ARKIV: red@tidskriftenarkiv.se · www.tidskriftenarkiv.se

ANSVARIg UTGIVARE \& CHEFREDAKTÖR: Sven Hort

ADMINistrativ RedAKTÖr: David Lindberg

RedAKtörer: Paavo Bergman, Lisa Kings, Zhanna Kravchenko 
Följande två artiklar av Göran Therborn publicerades ursprungligen i New Left Review (20I2 och 2014). Tillsammans tecknar de en välbehövlig översikt över vårt unga sekels nya klasslandskap.

Den första artikeln, "Klass i det tjugoförsta århundradet", tecknar en bakgrund av 1900-talet som arbetarklassens århundrade och ställer frågan om 2000-talet kommer att präglas av de nya globala medelklasserna. Therborn diskuterar olika möjliga klasskonstellationer och deras troliga politiska inriktning.

Den andra artikeln, "Nya massor? Motståndets sociala grundvalar", handlar om möjligheterna till radikal politisk mobilisering mot dagens globala kapitalism.

Redaktionen 


\title{
Böcker av Göran Therborn från Arkiv förlag
}

\author{
The Killing Fields of Inequality \\ (KOMMANDE PÅ SVENSKA)
}

Polity Press 2013, en översättning på Arkiv förlag kommer under 2015

Borgarklass och byråkrati i Sverige

Anteckningar om en solskenshistoria I86 sidor, Arkiv förlag 1989

Nationernas ofärd

Arbetslösheten i den internationella krisen 223 sidor, Arkiv förlag 1985

Maktens ideologi och ideologins makt I34 sidor, Zenit 198r i distribution från Arkiv förlag

Kapitalism och rösträtt

Om den borgerliga demokratins uppkomst

67 sidor, Arkiv förlag 1980

Vad gör den härskande klassen när den härskar?

Statsapparater och statsmakt under

feodalism, kapitalism och socialism

309 sidor, Zenit 1980 i distribution från Arkiv förlag

Frankfurtskolan

Till kritiken av den kritiska teorin

84 sidor, Arkiv förlag 1976

Klasser och ekonomiska system

328 sidor, Zenit 1971 i distribution från Arkiv förlag

"Böckerna går att beställa i bokhandeln och från www.arkiv.nu“ 


\title{
Klass i det tjugoförsta århundradet
}

\author{
GÖRAN THERBORN
}

\section{Arvet från arbetarklassens århundrade}

Även om 1900-talet kan förses med ett antal beteckningar som vore rimliga, var det i samhällshistorisk mening utan tvivel arbetarklassens tidsålder. För första gången blev arbetande människor som saknade egendom en viktig och varaktig politisk kraft. Denna brytning förebådades I89I av påven Leo XIII - ledare för världens äldsta och största samhällsorganisation - i sin påvliga encyklika Rerum novarum. Påven konstaterade att industrins utveckling hade medfört att "[r]ikedomarna har samlats i händerna på några få och det stora flertalet har lämnats i fattigdom”, men perioden kännetecknades också av att "[a]rbetarna har höjt tankarna om sig själva och skapat en starkare gemenskap mellan sig.” På global nivå fick fackföreningarna fotfäste i de flesta stora industriföretag och även på många andra håll. Arbetarpartier blev viktiga parlamentariska krafter - ibland dominerande - i Europa och dess förgreningar i Australasien. Oktoberrevolutionen i Ryssland fick stå modell för den politiska organiseringen och de sociala förändringarna i Kina och Vietnam. Nehrus Indien gav sig själv det uttalade målet att följa ett "socialistiskt utvecklingsmönster", liksom merparten av de postkoloniala länderna gjorde.

I. Här efter svensk översättning av Hugo Fiévet, publicerad på nätet 6 maj 20I2: http:// rerumnova.wordpress.com/20I2/05/06/hello-world, hämtat I november 2014.

Ursprungligen publicerad som "Class in the 2Ist Century" i New Left Review, nr 78 (2OI2). Här i en, av författaren, något reviderad och utvidgad version. 
Många afrikanska länder talade om att skapa "arbetarpartier" samtidigt som de inte kunde skryta med fler proletärer än att de kunde rymmas i ett par klassrum.

Firandet av första maj hade sin upprinnelse på Chicagos gator I886 och firades i Havanna och andra latinamerikanska städer så tidigt som I890. Den organiserade arbetarrörelsen visade sig bli en viktig kraft i Amerika, trots att den oftast hölls tillbaka. USA:s New Deal markerade ett sammanstrålande av den upplysta liberalismen och industriarbetarklassen, som tack vare hjältemodig kamp lyckades organisera sig under depressionsåren. Samuel Gompers var kanske en typisk representant för de trångsynta skråfackföreningar som föregick New Deal, men han var en magnifik förhandlare för de yrkesutbildade arbetare som hans rörelse företrädde, och han förärades ett monument i Washington som överträffade allt som tidigare förlänats arbetarledare i Paris, London och Västberlin. ${ }^{2}$

Mexikos lilla arbetarklass hade inte någon ledande roll i dess revolution - även om den inte heller var försumbar - men den postrevolutionära eliten lade mycket energi på att suga upp den organiserade arbetarrörelsen i sin maktapparat. Revolutionens första president Venustiano Carranza smidde sin sociala bas med hjälp av en pakt med Mexico Citys anarkosyndikalistiska arbetare (Casa del Obrero Mundial), och på 1930talet gav Lázaro Cárdenas den nya samhällsordningens struktur en uttalad arbetarinriktning (Davis 2004, s. 287-30I). Även om det knappast kan sägas om Getúlio Vargas och hans "nya stat" i Brasilien blev ett av arven efter den en rad progressiva arbetarlagar. I Argentina var det arbetarmobilisering, i synnerhet under ledning av militanta trotskister, som förde Juan Perón till makten, vilket säkrade en viktig röst åt den argentinska fackföreningsrörelsen - eller åtminstone dess ledning inom peronismen. Bolivias gruvarbetare spelade en avgörande roll under revolutionen 1952, och när tennproduktionen kollapsade på 1980-talet försåg den organisatoriska förmågan hos dem som tvingades söka arbete

2. Gompers övertrumfas - och det med rätta - av den irländska fackföreningsaktivisten Jim Larkin, som rakryggad står på Dublins viktigaste genomfartsled O’Connell Street, där han ledde en berömd sammandrabbning mellan strejkande och polisen under lockouten I9I3. 
på andra ställen Evo Morales och hans kokaodlare med en ryggrad av disciplinerade kadrer.

Det kanske största erkännandet av arbetarklassens centrala position under det förra seklet kom från den oberoende arbetarrörelsens mest fanatiska fiender, fascisterna. Idén om "korporativism" var grundläggande för Mussolinis Italien: korporativismen utgav sig för att föra samman kapital och arbete men i själva verket stängde den in arbetarrörelsen på ett område omgärdat av kapitalet och staten. Hitlers rörelse kallade sig Nationalsocialistiska tyska arbetarpartiet, och hans Tyskland blev det andra landet i världen - efter Sovjetunionen men före Sverige - att göra första maj till allmän helgdag, som "det tyska arbetets dag”. Under I900-talets första åttio år gick det inte att avskriva eller avfärda arbetarna. Stod man inte på deras sida måste man hålla dem under hård kontroll.

Arbetarna blev hjältar eller föredömen, inte bara för konstnärerna inom vänsterns avantgarde, från Brecht till Picasso, utan även för mer konservativa typer, som den belgiske skulptören Constantin Meunier - skapare av flera statyer avbildandes arbetare med olika yrken, och av ett ambitiöst Arbetets monument som restes efter hans död i Bryssel i närvaro av kungen. I Tyskland skrev den preussiske officeraren och författaren Ernst Jünger 1932 en beundrande essä, Der Arbeiter, som förutspådde slutet för det tredje ståndets herravälde och att det skulle ersättas av "arbetarnas herravälde och den liberala demokratin av arbetar- eller statsdemokrati" (Jünger 1982 [I932], s. 312).

Även om arbetarnas århundrade utan tvivel slutade i nederlag, desillusion och besvikelse, lämnade det efter sig varaktiga landvinningar. Demokratin som överordnad politisk modell är en, som det i dag krävs alldeles särskilda argument för att kränka. Den socialdemokratiska arbetarrörelsen var den främsta förespråkaren för demokratiska reformer, och följde därigenom sin engelska chartistiska föregångares exempel. Före 1918 var de flesta liberaler och samtliga konservativa övertygade om att demokratin inte var förenlig med bevarandet av privategendom, och krävde således allvarliga inskränkningar av rösträtt och parlamentens frihet (se även Therborn 1977). De mänskliga rättigheternas universella giltighet slogs fast i och med fascismens nederlag mot en interkontinental folkfront av kommunister, liberaler, socialdemokrater och konservativa som 
Churchill och de Gaulle, liksom genom de kontrarevolutionära militärdiktaturernas mer utdragna fall och den institutionella rasismens upphörande i Sydafrika och USA. Lönearbetarnas rätt att organisera sig och förhandla kollektivt var en annan stor framgång från efterkrigsperioden. På senare tid har konservativa krafter naggat dessa landvinningar i kanten i USA och Storbritannien, men samtidigt har de börjat få fotfäste i fler delar av världen, i de formella ekonomiska sektorerna i Afrika och Asien. De är fortfarande starka i Latinamerika och större delen av Europa.

Det går inte att förstå 1900-talet utan en fullständig uppfattning om dess stora revolutioner, den ryska och den kinesiska, och de djupgående återverkningar de fått på Östeuropa, Västindien liksom en stor del av Öst- och Centralasien - för att inte tala om deras inflytande över arbetarrörelsen och socialpolitik i Västeuropa. En utvärdering av dem är fortfarande politiskt kontroversiell och det vore, ur akademisk synvinkel, alltför tidigt att göra en sådan. Utan tvekan gav dessa revolutioner upphov till ett brutalt förtryck och händelser av övermodig modernistisk grymhet som orsakade utbrett lidande, som den svält som ägde rum under Stalins och Maos styre. Deras geopolitiska landvinningar är lika otvetydiga - även om vänstern knappast har det som kriterium för en lyckad prestation. Det förfallande, underutvecklade Ryssland, som besegrats av Japan 1905 och Tyskland 1917, blev Sovjetunionen: en stat som besegrade Hitler och etablerade sig som världens andra supermakt, och som för en tid verkade vara en allvarlig konkurrent till USA:s övermakt. Den kinesiska revolutionen gjorde slut på I50 års nedgång och förnedring för "Mittens rike", och förvandlade Kina till en global politisk kraft, innan dess utveckling i kapitalistisk riktning gjorde landet till världens näst största ekonomi.

I900-talets revolutioner har givit världen minst fyra viktiga progressiva arv. För det första fick utmaningen de utgjorde en avgörande inverkan på reformerna i den kapitalistiska världen efter kriget: omfördelning av jorden i Japan, Taiwan och Sydkorea, framväxt av sociala rättigheter i Västeuropa och reformer inom Framstegsalliansen i Latinamerika - alla inspirerades de av hotet från kommunismen. För det andra gjorde närvaron av ett rivaliserande maktblock med en egen ideologi mycket för att försvaga den europeiska och amerikanska rasismen och kolonialis- 
men. Eisenhower skulle inte ha skickat federala trupper för att skydda avskaffandet av segregationen inom skolorna i Arkansas om han inte hade varit intresserad av att vinna propagandakriget med Moskva. Två årtionden senare stoppade kubanska trupper den sydafrikanska armén när den skulle erövra Angola, och apartheidregimen skulle inte ha kunnat isoleras så effektivt utan den skugga som Sovjetunionen kastade över världspolitiken.

För det tredje: oavsett vad man har att säga om dess ledares skoningslösa envälde skapade den kommunistiska rörelsen en utomordentligt stor mängd självuppoffrande, hängivna kämpar över hela världen. Deras gränslösa beundran för Stalin och Mao var befängd men väldigt ofta var de också de fattigas och förtrycktas bästa - ibland enda - vänner. Detta engagemang i vardagen fordrar respekt från alla i den progressiva rörelsen. Slutligen, en inverkan vars omfattning kan ifrågasättas, har det lämnat efter sig ett organisatoriskt arv som fortfarande är av betydelse i det moderna samhället. De två stora revolutionernas länder fungerar inte längre som hoppets ledstjärnor, men de är avgörande om någon grad av geopolitisk pluralism ska kunna bevaras (detta innefattar det postkommunistiska Ryssland). Den fortsatta förekomsten av kommunistiskt styrda stater efter 1989-I99I innebär att det socialistiska alternativet i viss mån fortfarande står öppet. Om Folkrepublikens härskare skulle besluta sig för att Kina behöver en socialistisk ekonomisk bas för att förstärka sin nationella makt, eller att en fortsatt utveckling i kapitalistisk riktning skulle äventyra den sociala sammanhållningen, har de fortfarande makten och resurserna att byta inriktning.

Kommunistiska partier eller deras ättlingar har fortfarande fotfäste i många länder. Kommunismen har en betydande närvaro på den indiska politiska scenen, om än splittrad mellan rivaliserande styrkor: maoisterna för ett gerillakrig i stamregionerna, medan Indiens kommunistiska parti (marxisterna) vacklar i svallvågorna av historiska valnederlag efter att ha styrt delstaterna Kerala och Västbengalen. Det finns partier att räkna med i Grekland, Portugal, Japan, Chile och Tjeckien. De grekiska och portugisiska kommunisterna hade en viktig roll under arbetarnas mobiliseringar mot euroområdets åtstramningspolitik, och koalitionen SYRIZA, som leds av före detta eurokommunister, besegrades med knapp marginal 
i valen i Grekland i juni 2012. Ett av de mest innovativa resultaten av Europas kommunistiska tradition är Tysklands Die Linke, som förenar reformkommunister med vänstersocialdemokrater, och flera andra postkommunistiska grupperingar finns som är värda att nämna, från det svenska Vänsterpartiet till cypriotiska AKEL.

Det sydafrikanska kommunistpartiet utgör genom sin allians med ANC en del av regeringsblocket. Det brasilianska kommunistpartiet har en minoritetsroll i landets regering, vilket också de indiska kommunisterna hade ända till nyligen. Kommunismen har återvänt till parlamentet i Chile efter ett uppehåll på nästan fyrtio år efter Pinochets kupp, och den arabiska våren $20 I$ gjorde det möjligt för vänstergrupper med rötter i den kommunistiska traditionen att åter träda fram, även om de stannat kvar i det politiska livets marginal. Men den indonesiska demokratins pånyttfödelse har inte givit nytt liv åt partiet, som krossades 1965 vid en av århundradets största politiska massakrer - i relativ mening antagligen större än de stalinistiska utrensningarna 1937-1938. Det är anmärkningsvärt hur snabbt den kommunistiska traditionen på andra ställen gick upp i rök efter 1989 och dess partier antingen anammade en konservativ nationalism - vilket blev resultatet i Ryssland och de centralasiatiska republikerna - eller en högersocialdemokratisk samhällssyn, som blev fallet i Polen och Ungern. Italiens exkommunister ansåg snart att till och med ordet "social" var alltför vänstervridet och föredrog att titulera sig själva Demokratiska partiet, utan adjektiv, i ett försök att efterlikna amerikanerna.

Också den reformistiska delen av 1900-talets arbetarrörelse har givit oss ett bestående arv; det har bidragit till ett av de största regeringspartierna i de flesta länder i Europa i dag. Nu finns en fackföreningsrörelse av verkligt internationell omfattning - något som saknades för hundra år sedan - även om dess genomslag utanför Västeuropa är begränsad, där länder som Brasilien, Argentina och Sydafrika är unika med sina starka fackföreningar. Socialdemokratiska partier och arbetarpartier lever vidare, ofta med större valmanskårer än de kunde skryta med i början av förra seklet. Några nya områden har erövrats, i Latinamerika och delar av Afrika. Men Socialistinternationalen har ofta vunnit nya medlemmar genom att överge varje tillstymmelse till principer, och har tillåtit 
så osannolika progressiva som Laurent Gbagbo och Hosni Mubarak att ansluta sina politiska apparater.

En modern mitten-vänster-socialdemokrati kan fortfarande vara en progressiv kraft på vissa områden, och stödja rättigheter för kvinnor, barn och homosexuella. Men på den ekonomiska politikens område har dess partier i allt väsentligt kapitulerat för en liberalism av det ena eller andra slaget. Samhällsförändringar har undergrävt och politiskt marginaliserat dess ursprungliga bas i arbetarklassen. Under den pågående krisen i Europa har de socialdemokratiska partiernas prestationer sträckt sig från att vara slätstruket anständiga till att de fullständigt tappat orienteringen. Välfärdsstaten - en stat med medborgerliga sociala rättigheter - är 1900-talsreformismens viktigaste bedrift. För närvarande är den utsatt för angrepp och dåligt försvarad. Den nyckfulla Romneykampanjens enda konsekventa tema var dess angrepp på den europeiska modellens "rättigheter" (entitlements). Både de konservativa och New Labour i Storbritannien har i flera decennier nu underminerat den brittiska välfärdsstaten, även om det krävs fler valperioder för att få den fästningen att rasa. Välfärdsstaten har fått ta några hårda smällar i Natoländerna, framför allt i de länder där den redan från början var minst, men den kommer inte att monteras ner helt och hållet. I stället har dess politiska principer spridit sig internationellt, fătt genklang i Kina och andra asiatiska länder, och stärkt sitt grepp om stora delar av Latinamerika. Kina och Indonesien verkar inställda på att införa en allmän sjukvårdsförsäkring långt före USA.

\section{En förklaring till vänsterns nederlag}

Det gjordes alltså bestående progressiva landvinningar på I900-talet. Men man måste också förstå vänsterns nederlag när seklet närmade sig sitt slut. Den förhärskande europeisk-amerikanska teoretiska skolan kan inte förklara varför denna kapitalistiska kontrarevolution skulle visa sig bli så framgångsrik. Marx hade förutspått en sammandrabbning mellan produktivkrafterna och produktionsförhållandena - de ena alltmer samhälleliga till sin natur, de andra privata och kapitalistiska - som med tiden skulle bli allt hårdare. Det var den marxistiska "stora dialektiken", 
och berövad sin apokalyptiska drapering visade den sig med tiden vara riktig. Det typiska var att kommunikationer, transporter, energi och strategiska naturtillgångar avlägsnades från den rent kapitalistiska sfären och ställdes under statligt ägande eller sträng reglering. De olika regeringarnas ideologiska färg kanske påverkade vilken form denna process antog, men sällan dess innehåll. Offentliga investeringar inom utbildning och forskning blev avgörande för den ekonomiska konkurrensförmågan - och uppnåddes i USA med hjälp av medel till försvaret, vilket bland annat blev upphovet till GPS och internet.

1970-talet var höjdpunkten för 1900-talets arbetarrörelse när det gällde facklig organisering och stridbarhet - det var en tid då det brittiska gruvarbetarfacket kunde fälla regeringen Edward Heath - och genomslagskraften hos den breda allmänheten för radikala idéer var som störst, från den svenska socialdemokratins förslag om löntagarfonder till den franska vänsterns gemensamma program med krav på omfattande nationaliseringar och en "brytning med kapitalismen”. Då var det få som insåg att detta var krönet på framgångarna före fallet. En av få framstående analytiker som gjorde det var den framlidne Eric Hobsbawm i sin föreläsning från 1978, "The Forward March of Labour Halted?”3 Den nya tidens politiska prägel hade ännu inte satt sig, men det var inte långt kvar: Thatchers och Reagans valsegrar 1979-1980 följdes av regeringen Mitterands kapitulation för nyliberalismen 1983 och de svenska socialdemokraternas övergivande av Meidnerplanen.

Den "stora dialektiken" hade tills vidare upphävts, till och med kastats om. Nyliberalismens seger handlade inte bara om ideologi. Som marxister borde förvänta sig stod den på stadig materiell grund. Finansialiseringen - en rad processer inbegripande liberalisering av kapitalfödena, kreditexpansion, digital handel och samlandet av kapital i pensions- och försäkringsfonder - skapade enorma mängder koncentrerat privat kapital, som spreds utanför finansvärldens nya kasinon. Sommaren 201 ir hade Apple mer likvida medel än USA:s regering. Den elektroniska revolutionen gjorde det möjligt för privata företagsledningar att verka över stora avstånd, upprätta globala varukedjor och upplösa den gamla ekonomiska

3. Hobsbawm 1978. I ärlighetens namn måste jag säga att jag på den tiden förhöll mig skeptisk till hans argument, vilket jag diskuterar i Therborn 1984. 
storskaligheten. I denna omvandlade omgivning ersattes nationalisering och reglering av privatisering och marknadsanpassning som allestädes närvarande kärna i regeringarnas politik.

Jämte den stora dialektiken kan vi tala om en "liten dialektik", som förutsåg att den kapitalistiska utvecklingen skulle göra arbetarklassen starkare och skärpa dess motstånd mot kapitalet. Även detta tog till reträtt när de rika länderna började avindustrialisera. Här måste vi inse att det skett en epokgörande strukturell förändring som minskat industrins betydelse för den utvecklade kapitalismen, en förändring som tog sin början just innan arbetarklassens makt var som störst. Sedan lämnade tillverkningen Europa och Nordamerika. Den "lilla dialektiken" hade en långsam påverkan på de nya industriella produktionscentrumen - framför allt i Östasien. Men nu kan vi spåra dess konsekvenser, som först blev synliga i Sydkorea på 1980-talet och som för närvarande sprider sig över hela Kina - även om arbetarnas organisering och protester oftast är begränsade till att vara lokala. De kinesiska lönerna och arbetsförhållandena håller på att förbättras betydligt. 2002 hade Kina mer än dubbelt så många anställda inom industrin som alla G7-länder sammanlagt (Banister 2005, s. II).

\section{Stater och klasser}

Det är aningen ironiskt att vi kan tala om 1900-talet som att det var arbetarklassens århundrade. Även om det som ett resultat av arbetarklassens kamp kanske var en tid av utjämning inom länder, var det också en tid av största möjliga ojämlikhet mellan länder på global nivå. ”Underutvecklingens utveckling" under I800- och I900-talen innebar att ojämlikheten mellan människor till största delen bestämdes av var de bodde. År 2000 beräknades det att 80 procent av inkomstskillnaderna mellan hushåll kunde tillskrivas landet de bodde i (Milanovic 20II, s. II2). På 2000-talet närmar sig i stället länderna varandra medan klasserna glider isär.

De två senaste decennierna har varit goda för världens fattiga länder. Asiens ekonomiska motor - Kina, Indien och medlemsstaterna i ASEAN - har vuxit dubbelt så fort som det internationella genomsnittet. Efter att så tragiskt ha halkat efter under 1900-talets sista fjärdedel har också 
Afrika söder om Sahara sedan 200I vuxit mer än övriga världen och dess "utvecklade ekonomier”. Även Latinamerika har sedan 2003 i allmänhet överträffat de utvecklade länderna. Med undantag för det postkommunistiska Europa klarade sig "utvecklingsekonomierna" också bättre undan den anglosaxiska bankkrisen än den rika världen. Här tror jag att vi håller på att uppleva en historisk vändning, inte bara geopolitiskt utan också i fråga om ojämlikhet. Totalt sett minskar ojämlikheten mellan länder, även om klyftan mellan de rika och de fattigaste inte har slutat växa. Men på det hela taget ökar ojämlikheten inom länderna - om än med ojämn spridning, ty vi kan inte tala om någon allomfattande logik av globalisering eller teknologisk förändring utan att göra våld på fakta.

Detta innebär att klass återvänder, mäktigare än någonsin, som en avgörande faktor för ojämlikhet. Trenden tog sin början på I990-talet, vid en tidpunkt då inkomstklyftorna i Kina växte sida vid sida med dem $\mathrm{i}$ det postsovjetiska Ryssland, medan den blygsamma tendensen till utjämning på landsbygden i Indien slogs tillbaka. I Latinamerika fick Mexiko och Argentina stå ut med törnarna från nyliberalismen. En studie från Internationella valutafonden har visat att den enda grupp på internationell nivå som ökade sin andel av inkomsterna på 1990-talet var ländernas rikaste femtedel, både i hög- och låginkomstländer (IMF 2007, s. 37). Alla de fattigaste femtedelarna förlorade. De viktigaste förändringarna har ägt rum i toppen av inkomststegen. Från 198I till 2006 har de rikaste o,I procenten ökat sin andel av inkomsterna i USA med sex procentenheter. Resten av den ökända I procenten ökade den med fyra procentenheter. De 9 procenten närmast under dem ökade eller behöll sin andel, medan de återstående nio tiondelarna av befolkningen tappade mark (IHT 200I; Krugman 20II). Under ett år av blygsam återhämtning efter krisen 2008-2009 har den rikaste percentilen lagt beslag på förbluffande 93 procent av alla inkomstökningar i USA (Lowrey 20I2).

Samma ojämlika trend har synts i Kina och Indien, även om andelen av välståndet som tillfaller den rikaste procenten är mycket mindre än i USA: omkring Io procent i Indien och 6 procent i Kina (före skatt) (Atkinson \& Piketty 20Io, s. 46). Det indiska "miraklet" har nästan inte gjort någonting för den fattigaste femtedelen av de indiska barnen, av vilka två tredjedelar var underviktiga 2009 - precis som de var 1995. 
De snabba inkomstökningarna under 200o-talets första årtionde i en stor del av den tidigare tredje världen påverkade inte den globala svälten särskilt mycket: mellan 2000 och 2007 ökade antalet undernärda människor från 8I8 till 837 miljoner och livsmedelspriserna fortsatte att stiga (FN 20II, s. II-I4). I andra änden av skalan firade tidskriften Forbes rekorden som slogs av gruppen miljardärer i mars 20I2: de var fler än någonsin - I 226 inklusive 425 amerikaner, 95 kineser och 96 ryssar och hade en samlad förmögenhet på 4,6 biljoner dollar, vilket var större än Tysklands BNP (Forbes, 7 mars 20I2). Vi ska inte förutsätta att denna utveckling var oundviklig. Efter att sedan länge ha varit en av världens mest ojämlika regioner har Latinamerika gått i motsatt riktning och är nu det enda ställe där ojämlikheten minskar (CEPAL 2oıo; Cornia \& Martorano 20IO; UNDP 20IO). Det återspeglar en folklig motreaktion mot militärregimernas och deras civila efterträdares nyliberalism, med en omfördelningspolitik som under det senaste decenniet antagits av Brasilien, Argentina, Venezuela bland andra.

Ett annat sätt att jämföra klasser över nationsgränserna är att beräkna deras Human Development Index (HDI, Index för mänsklig utveckling), vilket innefattar inkomst, beräknad livslängd och utbildning - en hjälteinsats och mycket komplicerad operation med betydande felmarginaler. Icke desto mindre ger det en användbar uppfattning om världens ojämlikhet. Den fattigaste femtedelen i USA har ett lägre HDI än den rikaste femtedelen i Bolivia, Indonesien och Nicaragua. Det är lägre än de 40 procent mest lyckligt lottade brasilianarna och peruanerna, och på samma nivå som den fjärde femtedelen i Colombia, Guatemala och Paraguay (Grimm m.fl. 20I0). Klasstillhörighetens betydelse kommer troligen att öka också av andra skäl än ländernas ekonomiska konvergens. Orättvisor grundade på kön och rastänkande är långtifrån utrotade, men de har förlorat en del av sin betydelse - ett viktigt exempel på det är apartheidregimens fall i Sydafrika. Sedan den institutionaliserade rasismen upphört kan detta land nu visa upp ett av de mest dramatiska exemplen på klasspolarisering. Ekonomer på Världsbanken har beräknat att Gini-koefficienten för inkomstskillnader mellan världens hushåll i början det nya seklet låg mellan 0,65 och 0,70. Men 2005 var den 0,75 i Johannesburg (Milanovic 20I2; UN-HABITAT 2008, s. 72). Även om vi 
räknar med felmarginaler kan vi dra slutsatsen att en enda stad rymmer lika mycket ojämlikhet som hela världen.

2000-talets klasser och klassmotsättningar kommer att utvecklas i två nya konfigurationer, båda övervägande icke-europeiska och med tyngdpunkten långt söder om Natoländerna. En kommer troligen att drivas fram av medelklassens förhoppningar och missnöje. En annan kommer att ha sin bas hos arbetare och i de folkliga klasserna i hela deras mångfald - plebejerna snarare än proletariatet. För båda dessa former kan vi urskilja två tänkbara vägar framåt.

\section{Medelklassens århundrade?}

En uppfattning håller redan på att utkristallisera sig om att 2000-talet är den globala medelklassens tidsålder. Förra seklets arbetare slås ur tankarna. Ett projekt för allomfattande frigörelse under ledning av proletariatet ersätts av en allmän strävan efter att uppnå medelklasstatus. ”Den unga medelklassen kommer att bli den drivande kraften i de asiatiska samhällena", menade den kommunistiska enpartistaten Vietnams vice statsminister vid det östasiatiska världsekonomiska forumet $2009,{ }^{4}$ och Dilma Rousseff, den före detta gerillakämpen som ersatte Lula som president i Brasilien, har förkunnat en önskan om att "förvandla Brasilien till en medelklassbefolkning" (Leahy 20I2). ${ }^{5}$ OECD:s översikt över utsikterna för den internationella utvecklingen 2012 talade om behovet av att "stödja den framväxande medelklassen", medan Nancy Birdsall från Center for Global Development har hänvisat till den "oumbärliga medelklassen” och uppmanat de politiskt ansvariga att byta mål från "tillväxt för de fattiga" till "tillväxt för medelklassen" (OECD 20II, s. I03; Birdsall 20IO).

Trots dess påstått centrala roll varierar definitionen av detta samhällsskikt avsevärt. Låt oss studera tre försök att kartlägga dess konturer inget går att dra några långtgående slutsatser ifrån, men alla är belysande.

4. Från Världsekonomiskt forums nyhetssida på internet, http://www.weforum.org/ news/asian-middle-class-drive-growth, hämtat I november 2014.

5. Redan hennes politiske mentor Lula hade talat om sina förpliktelser mot den framväxande medelklassen när han ställde upp för omval 2006: "Brasilien upplever framväxten av en ny medelklass. Om jag blir omvald kommer jag att ge denna grupp särskild uppmärksamhet" (Bourne 2008, s. 204). 
Martin Ravallion från Världsbanken placerar medelklassen i utvecklingsländerna i inkomstspannet mellan 2 och 13 dollar per dag. Den första siffran är Världsbankens egen tröskel för fattigdom, den andra markerar gränsen för fattigdom i USA. Han fastställer en ökning av denna "medelklass" från en tredjedel av utvecklingsländernas befolkning 1990 till nästan hälften 2005 - en ökning i absoluta tal med I,2 miljarder. Detta skikt skulle omfatta nästan två tredjedelar av kineserna men bara en fjärdedel av dem som bor i Sydasien och Afrika söder om Sahara (Ravallion 20IO). Nancy Birdsall, som ser medelklassen som en liberal politisk aktör, lägger ribban högre, ıo dollar per dag. Hon är angelägen om att skilja medelklassen från dem som kan betecknas som rika: inkomsten får inte göra att du hör till de rikaste 5 procenten av dina landsmän. Med detta mått mätt är den kinesiska landsbygdens medelklass försumbar. Samma sak gäller Indien, Pakistan, Bangladesh och Nigeria. I Kinas städer hamnar 3 procent i denna kategori, i Sydafrika 8 procent. Siffran stiger till 19 procent i Brasilien och 28 procent i Mexiko, och når sin högsta nivå på 9I procent i USA (Birdsall 2oro, appendix, tabell 3, 4, 7).

Två framstående fattigdomsekonomer, Abhijit Banerjee och Esther Duflo, för fram ett perspektiv grundat på internationella kartläggningar av hushåll i tretton länder - inklusive Tanzania, Pakistan och Indonesien - främst av dem med en inkomst på mellan 2 och ıo dollar per dag, och frågar sig vad, i detalj, som är medelklass hos dem. Den mest anmärkningsvärda upptäckten är att denna "medelklass" inte präglas av större entreprenörsanda i sin inställning till sparande och konsumtion än de fattiga som hamnar under tröskeln på 2 dollar. Det utmärkande hos dess medlemmar är att de har ett fast, avlönat arbete (Banerjee \& Duflo 2007). Man skulle alltså kunna beskriva dem som att de har en stabil arbetarklassposition snarare än att de tillhör en vagt definierad medelklass. Den brasilianska regeringen har en benägenhet att betona medelklassens sårbarhet; den sägs vara ständigt i riskzonen för att falla tillbaka i fattigdom och kräver därför stöd och omsorgsfull uppmärksamhet (Barros m.fl. 20II). I Asien - särskilt Östasien - är samma omsorg inte självklar.

I Kina har medelklassen eller mellanskiktet blivit ett stort diskussionsämne för forskare och medier sedan slutet av 1990-talet. Dessförinnan var allt tal om medelklass förbjudet, och en del av dess förkämpar klagar 
fortfarande över det "ideologiska tryck" som förnekar klassen fullständig social legitimitet (Zhou 2008, s. I24). I dag tenderar kinesiska forskare att idealisera medelklassen och stödjer sig på amerikanska stereotyper samtidigt som de undviker en kritisk diskussion av begreppet (se Rocca 20I2, s. 36). Medelklassen ses som kinesiska mediers främsta publik, och mediernas sätt att närma sig den är till stor del inspirerad av amerikanska publikationer - från Vogue till Business Week - som nu är allmänt tillgängliga i Kina (Jin 20I2). Den har också uppfattats som ett bålverk för politisk stabilitet och återhållsamhet de kommande åren. Men en del klarsynta kommentatorer har konstaterat att det är de ökande inkomstklyftorna som har lagt grunden till denna nya medelklass: Kina är nu Asiens mest ojämlika land, och dess Gini-koefficient har rusat i höjden från 0,2I på 1960-talet (ungefär där Sverige befann sig 1980) till o,46 i dag (Zhou \& Chen 20I2, s. 52). I kölvattnet efter den ekonomiska liberaliseringen har också Indien bevittnat uppkomsten av en skrytkonsumtion inom medelklassen, och en politisk marknadsföring som hinduhögerns valparoll 2004 var ett typexempel på: "Lysande Indien”. Men det ideologiska landskapet var mycket mer komplicerat och omtvistat än i Kina. Kritiska röster höjdes mot en klass som sades vara "utan moraliskt roder, överdrivet materialistisk och socialt okänslig" (Varma 1998, s. I74). Kampanjen "Lysande Indien" slog slint och Kongresspartiet återfick makten.

\section{Konsumtion eller demokrati?}

I en värld där arbetarklassen och socialismen har förklarats obsoleta har medelklassamhället blivit en symbol för en alternativ framtid. Nordatlantens utvecklade länder döps i efterhand om till "medelklassamhällen" - trots att det är ett amerikanskt begrepp som egentligen aldrig slog igenom i Europa. Kärnan i denna utopi är drömmen om en gränslös konsumtion, om att medelklassen tar över jorden, köper bilar, hus och en oändlig uppsättning elektroniska varor och håller igång en global turistindustri. Även om denna globaliserade konsumism utgör en mardröm för ekologiskt medvetna människor får den det att vattnas i munnen på affärsmän och deras tidningar. Medelklassens konsumtion har också den stora fördelen att den tillgodoser de rikas privilegier samtidigt 
som den utgör en stillsam horisont för de folkliga klasserna att drömma sig bort till. Den mörka sidan av drömmen är dess inneboende utestängande karaktär. De som inte tillhör medelklassen - eller de rika - står utan försonande drag och tillgångar. De är bara "förlorare", som det framställdes av det tv-sända skränande som fick Tea Party-rörelsen i USA att ta fart 2009 (Skocpol \& Williamson 20I2, s. 7). De är "underklassen”, "chavs". ${ }^{6}$ I utvecklingsländerna är "upprensningen" av offentliga platser ett uttryck för denna lömska tendens, där fattiga finner sig utestängda från stränder, parker, gator och torg. Ett särskilt upprörande exempel är inhägnandet av Merdekatorget (Självständighetstorget) i Jakarta med sitt fallosliknande nationalmonument, vilket förvandlade det till "en sorts fritidsanläggning för enbart medelklassen" och berövade de fattiga deras enda rekreationsområde (Leeuwen 20II, s. 64, I92; Fernandes 2006, kap. 4, ger en liknande bild från Mumbai).

Liberala medier ser en uppåtstigande medelklass som en förtrupp för demokratiska reformer. Men forskarnas diskussion om den asiatiska medelklassen är mycket mindre sentimental angående dess troliga politiska roll. En viktig forskningsanalys drog slutsatsen att "medelklassen tenderar att vara 'situationsbunden' i sin inställning till reformer och demokrati” (Hsiao 2006, s. 7). Avskyn för den indiska politiska klassen har lett till ett ovanligt politiskt fenomen, med lägre valdeltagande högre upp på samhällsstegen än bland de tidigare "oberörbara" - daliterna och de fattiga. Vid valet 2004 röstade 63,3 procent av daliterna men bara 57,7 procent från de högre kasterna (Jaffrelot 2008, s. 47). Bittra erfarenheter från I900-talet har redan lärt latinamerikanerna att medelklassen inte är demokratisk till sin natur, då delar av den aktivt motarbetade demokratin i Argentina (1955-1982), Chile (1973) och Venezuela (2002). Den är "situationsbundet" (opportunistiskt) demokratisk - eller antidemokratisk.

Det finns ett annat medelklasscenario, i förbigående nämnt i Birdsalls paper (20IO), som förutser en konfrontation mellan de rika och alla andra, där medelklassen spelar en viktig roll bland de sistnämnda. Som

6. Se Jones 20II. - "Chav" är ett brittiskt slangord som kommit att användas som en starkt förolämpande benämning på unga personer från arbetarklassen med ohyfsat beteende och "dålig smak". Övers. anm. 
Hongkong-forskaren Alvin So har konstaterat kan Östasien användas som försvar för denna tes, eftersom regionen ofta haft medelklassakademiker "i frontlinjen under statsfientliga protester" - för att inte nämna demonstrationer mot Internationella valutafonden och den amerikanska militarismen (So 2006, s. 32). Detta förbund mellan medelklassen och massorna mot oligarkin var centralt för "folkens vår" 1848, och en genklang av det kunde höras under upproren på båda sidor av Medelhavet 20II. I Kairo och Tunis, Barcelona och Madrid, marscherade medelålders människor från akademikeryrken jämsides med studenter och arbetslösa ungdomar. De som tillhörde den förstnämnda gruppen var ofta föräldrar till den andra - en solidaritet mellan generationerna som 1968 års radikaler aldrig upplevde.

Även om ingen demokrati borde göra sig beroende av en medelklass finns det tillfällen när medelklassens mobilisering mot ett auktoritärt styre har varit avgörande. På grund av landets storlek och betydelse i regionen är 2000-talets hittills viktigaste medelklassrevolution utan tvivel revolutionen i Egypten. Det är givetvis alldeles för tidigt för att dra några bestämda slutsatser, $\mathrm{i}$ synnerhet såhär utifrån, men vi kan våga oss på några få observationer. Även om revolutionen utlöstes av händelser och krafter utanför landet har finanskrisen på norra halvklotet ingenting med den att göra: en analys av den egyptiska ekonomin från Internationella valutafonden strax före Mubaraks fall förutsade en uppgång av levnadsvillkoren i landet. Den utlösande faktorn var upproret i Tunisien. Precis som i resten av Nordafrika hade omfattningen av den högre utbildningen vuxit snabbt på senare år - inklusive utbildningen av kvinnor, vilket har naggat det officiella patriarkatet i kanten. Men denna nya utbildade medelklass bestod till stor del av arbetslösa eller undersysselsatta akademiker (Mason 20I2; Castells 20I2). Det fanns inget egyptiskt bildningsborgerskap.

Dessutom var den politiska regimen inte bara korrumperad och förtryckande, den hade inte heller några framtidsutsikter att erbjuda, vare sig till den nya kullen akademiker eller till deras underbetalda föräldrar. Hazem Kandil har uppmärksammat den "murbräckseffekt" som den nyliberala klicken som samlades kring arvingen Gamal Mubarak fick. Det som återstod av arvet efter Nasser överlämnades då till privata pam- 
par. Regimen kapade själv de band som hade knutit medelklassen till den (Kandil 20I2). Precis som i Europa I848 deltog också den egyptiska arbetarklassen i den revolutionära processen, även om det inte var som dess viktigaste kraft: minnet av tidigare strider - som den kvästa strejken vid al-Mahalla al-Kubra 2008 - bidrog i stor utsträckning till mobiliseringen (Mason 20I2, s. IO). Men Egyptens medelklassrevolution ställdes snabbt inför "adertonde brumaire"-problemet, nämligen sprickan mellan de radikala elementen som var koncentrerade till städerna och en till största delen konservativ, mycket större, landsbygdsbefolkning. De egyptiska radikalerna led nederlag i valet, precis som deras föregångare ett och ett halvt sekel tidigare. Det betyder inte att resultatet av 20II års revolution helt kommer gå om intet - lika lite som Napoleon III:s seger utraderade landvinningarna från I848. Men det pekar verkligen på medelklassupprorens svaghet, även i deras starkaste och mest radikala form.

Medelklassens "globala konsumism" är i dag en realitet, vilket ett besök till köpcentrum i Lima, Nairobi eller Jakarta vittnar om. Icke desto mindre är de liberala akademikernas och marknadskonsulternas konsumtionsdrömmar fortfarande till största delen prognoser inför framtiden. Förhoppningar om politisk stabilitet har kommit på skam när medelklassens uppror har trätt in mitt på scenen. Yttringarna av denna rebelliska anda varierar betydligt till form och ideologi: revolutionerna i Nordafrika, Anna Hazares kampanj mot den politiska korruptionen i Indien, Tea Party-rörelsen i USA, aktivt stöd från Chiles medelklass till den radikala studentrörelsen. Samma land kan till och med ge upphov till rivaliserande medelklassrörelser - vilket var fallet i Thailand, där de konservativa gulskjortorna utmanades av de plebejiska och lantliga rödskjortorna. Vi ska inte bli överraskade om vi får bevittna fler omvälvningar när en ilsken medelklass går ut på gatorna med oförutsägbara resultat.

\section{Arbetarklassens möjligheter}

Det kan kännas som att det var alldeles nyss som arbetarklassen sågs som samhällsutvecklingens framtid, men det är osannolikt att den tiden kommer att komma tillbaka. Industrikapitalismens höjdpunkt i Europa och Nordamerika gav dess främsta motståndare, arbetarrörelsen, auktoritet, 
precis som Marx hade förutsagt. Men den tiden är förbi. De utvecklade ekonomierna avindustrialiseras och deras arbetarklasser har splittrats, besegrats och berövats tron på sig själva. Den industriella stafettpinnen har överlämnats till Kina, som framväxande centrum för världens tillverkningskapacitet. I och med det kvarvarande bukou-systemet ${ }^{7}$ med skilda medfödda rättigheter för stadsbor och landsbygdsbor är industriarbetarna i Kina fortfarande till stor del invandrare i sitt eget land. Ändå stärker Kinas industriella tillväxt arbetarnas ställning, precis som Marx skulle ha förväntat sig: strejker har blivit vanligare och löner stiger. Det är inte uteslutet att en ny omgång samhällskonflikter uppstår om fördelningen av välståndet, nu flyttat från Europa till Östasien. De kinesiska myndigheterna är givetvis medvetna om detta, och den kinesiska arbetslagstiftningen har som mål att hålla tillbaka en otyglad kapitalism. Mest anmärkningsvärt i detta avseende är den lag om arbetsavtal som trädde i kraft 2008. Samtidigt dyker det upp "rådgivningscentraler" för arbetarna, många av dem med stöd från utländska finansiärer. Ibland kan de etablera kontakt med de officiella fackföreningarna eller de lokala partikommittéerna. Men det finns troligen många fler fall där det lokala styret sluter upp bakom arbetsgivarna (Cooke 20II; Cheng, Ngok \& Zhuang 20IO). Hur som helst skapar ny lagstiftning, kvarvarande rester av det kommunistiska arvet och spridning av elektroniska medier mer utrymme för en oberoende arbetarorganisering, som inte kommer att förändra Kinas samhällssystem på kort sikt men kan ge arbetarna bättre avtal inom de nuvarande ramarna. Kroppsarbetare är en kraft man måste räkna med i Kinas städer, även om det är svårt att avgöra hur många de är till antalet. Den bästa uppskattningen verkar vara att de utgör en tredjedel av den registrerade befolkningen. ${ }^{8}$ Men gästarbetare utan uppehållstillstånd utgör mer än en tredjedel av den totala arbetskraften i städerna, och den stora merparten av dem är kroppsarbetare inom tillverkning, byggnads-

7. Hukou-systemet registrerar alla viktiga uppgifter om kinesiska medborgare som födelseplats, födelsedatum och civilstatus. Det styr också var en medborgare har rätt att bosätta sig och åtnjuta sociala rättigheter. Den största skiljelinjen går mellan dem som kategoriseras som stadsbor respektive som landsbygdsbor, och rätten att vara bosatt i städerna är strikt reglerad. Övers. anm.

8. Chunling 20I2, s. 96; för en annan uppskattning se Xin 2012 (i samma antologi), s. II2. Data för analysen har tagits från Kinas folkräkning 2003. 
industri och servering (Shi 2008; OECD 2007). Om dessa två grupper slås samman bör de utgöra mellan drygt hälften och två tredjedelar av den ekonomiskt aktiva urbana befolkningen. Framväxten av en mäktig rörelse med detta proletariat som grund skulle kunna ha en enorm inverkan på utvecklingsländerna, men vi kan knappast beskriva de framtidsutsikterna som troliga.

På andra ställen förefaller politiska omvandlingar med arbetarpartier i spetsen ännu mer osannolika - vare sig de är revolutionära eller reformistiska till sin natur. Indiens industriklass är mindre än sin kinesiska motsvarighet: lite mer än en sjättedel av arbetskraften till skillnad från en fjärdedel i Kina. Familjeföretag och egna företag dominerar fortfarande (Therborn 20I2, s. 194, tabell 4.6). Bland dem som får regelbunden lön finns en betydande facklig organisering, uppskattad till 38 procent (Ferus-Comelo 2007, s. 479). Men dessa arbetare är uppdelade på tolv nationella fackförbund, med de viktigaste knutna till politiska partier. Indiens fackliga styrka nådde sin hittillsvarande högsta nivå i början av I980-talet, men led förkrossande nederlag i de båda industriella centrumen: textilfabrikerna i Mumbai och Calcuttas juteindustri (Sen 1997, s. 464). Indiens fackföreningar har haltat vidare, men inte lyckats utöva någon attraktionskraft på de breda fattiga arbetarmassorna (jfr Breman 20Iо, kap. Iо).

Efter Suhartos fall har den indonesiska fackföreningsrörelsen återuppstått, men främst i form av fabriksförbund koncentrerade till den formella sektorn - som bara står för en tredjedel av arbetskraften - och med en övervikt av tjänstemän, exempelvis inom banksektorn. 2003 års arbetskraftslag har förstärkt de lagliga rättigheterna för dem med fast anställning. Men arbetarklassen står långt ifrån att vara en viktig samhällelig aktör, och även inom den formella sektorn är bara omkring en tiondel fackligt anslutna. Hittills har alla försök att skapa ett arbetarparti misslyckats (Ford 2007). 20I2 firades första maj av en folkmassa på 9000 arbetare, omgivna av I6 ooo poliser. Det är osannolikt att Sydkorea, en av den asiatiska industriutvecklingens pionjärer, kommer att kunna skapa en rörelse som är jämförbar med dem i 1900-talets Europa, även om dess fackföreningar fortfarande har stor betydelse. Den våldsamma exploateringen av arbetarna under kalla krigets militärregimer blev en av 
de frågor som den demokratiska oppositionen samlades kring på 1980talet. Det var också höjdpunkten för den koreanska fackföreningsrörelsen, med en femtedel av arbetarna organiserade i arbetarrörelsen. Den fackliga organiseringen har sedan dess urholkats av avindustrialisering och ökad sysselsättning inom servicesektorn (Lee 20II, s. 28, 55). Trots det har ett av fackförbunden lyckats skapa ett parti som finns representerat i parlamentet i Seoul. När jag senast besökte Korea, i december 20II, fanns stora förväntningar om en sammanslagning av vänster- och mitten-vänster-partierna, men denna process bröt till slut samman.

Den ryska arbetarklassen som gjorde revolution 1917 blev till största delen utplånad under det efterföljande inbördeskriget, och den nya arbetarklass som uppstod under sovjetstyret handlingsförlamades av kapitalismens återupprättande på 1990-talet. Strejkvågorna 1989 och I99I bidrog till Gorbatjovs fall, men det postsovjetiska Ryssland hade ännu mindre att erbjuda arbetarna än det gamla systemet, och under det följande årtiondet sjönk den förväntade livslängden kraftigt. Kommunistpartiet är fortfarande en parlamentarisk kraft av viss betydelse, men den stödjer sig snarare på en bakåtblickande nationalism än på någon sorts vänsterideologi. Ingen socialdemokratisk organisation har lyckats etablera sig. Den ryska fackföreningsfederationen är fortfarande betydande sett till medlemssiffrorna men har gjort föga för att skydda arbetarnas intressen (Ashwin 2007).

Fackföreningsrörelsen som byggdes upp av industriarbetarna i São Paulo har skapat ett framgångsrikt politiskt språkrör, Arbetarpartiet (PT), vars kandidat valdes till president, en mycket populär sådan, i Brasilien 2002 vid det fjärde försöket. Arbetarpartiet har förvandlat landets sociala landskap, tagit sig an den extrema fattigdomen, byggt ut skolväsendet och dragit in fler arbetare i den formella arbetskraften där deras rättigheter är skyddade av lagen. ${ }^{9}$ Men det har alltid varit en samling av många olika sociala rörelser, och dess presidenter och regionala ledare har tvingats utöva sin makt genom att lita till skumma nätverk byggda på klientelism. Som vi redan konstaterat strävar Dilma Rousseff i dag mot ett "medelklass-Brasilien", inte mot ett land av arbetare eller

9. Antalet arbetare som registrerats i den formella sektorn steg från 45 procent 2002 till 50 procent 2008 (Berg 20II, s. I28). 
lönearbetare. Ändå finns fortfarande en av de starkaste vänsterkrafterna bland världens "jättestater" i hennes land, och erbjuder de ljusaste framtidsutsikterna för samhälleliga förändringar.

Sydafrika är en annan växande ekonomisk makt med en stark och välorganiserad arbetarrörelse som var en del av den koalition som ledde kampen mot apartheid. Men efter maktövertagandet 1994 har ANC prioriterat att skapa en svart ekonomisk elit: ett slående exempel på denna process är den tidigare gruvarbetarledaren Cyril Ramaphosa, som har blivit förmögen affärsman. Trots en avsevärd minskning av den extrema fattigdomen var ojämlikheten troligen större 2009 än vad den var när apartheid avvecklades. ${ }^{10}$ Den enorma gruvstrejken som inleddes i augusti 2012 startades av en ny, konkurrerande fackförening: protesterna bemöttes först med ett dödligt förtryck och användandet av lagar från apartheidtiden. Oavsett slutresultatet av denna strejkvåg ligger arbetarklassens möjliga herravälde i Sydafrika mycket långt i färran. På annat håll på kontinenten beslutade Nigerias fackföreningsfederation 2002 att starta ett arbetarparti med stöd från EU och den tyska Friedrich Ebertstiftelsen. Men det visade sig vara en dödfödd skapelse, och dess ledare rörde sig inom kort mot traditionella politiska former grundade på politiskt beskyddarskap (Beckman \& Lukman 20IO).

Det går inte att urskilja någon marsch framåt för arbetarna i klassisk mening i dagens värld, men vi kan ändå se att det görs framsteg på olika fronter. Relationen mellan arbete och kapital breder ut sig och kommer

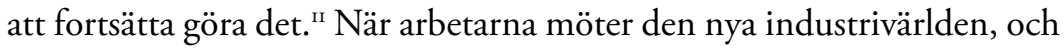
med tiden blir starkare och ambitiösare genom att organisera sig, kan vi förvänta oss att de kommer att ställa sina egna krav. Det kanske är svårt att tänka sig att Marx "lilla dialektik" av klasskamp plötsligt kommer att framkalla en omvandling av samhället, men kapitalismens utbredning och den ökande ojämlikheten säkerställer att arbetarklassen även fortsatt har en plats på 2000-talets politiska scen.

IO. Economist rapporterade en Gini-koefficient för 2009 på 0,63, mot 0,59 år I993 - även om det kan ha funnits mätskillnader som försvårar en direkt jämförelse (Economist, 20 oktober 2012).

II. För närvarande omsluter den ca 40 procent av världens arbetande befolkning. Bland de övriga arbetar en tredjedel i egna företag, en sjättedel inom familjen och runt en tiondel i offentlig sektor. Se Therborn 2012, s. I89, tabell 4.5. 


\section{Underklassens framtidsutsikter}

Den röda fanan har överlämnats från Europa till Latinamerika, den enda del i världen där socialismen står på dagordningen för närvarande, med regeringar i Venezuela, Ecuador och Bolivia som talar om "200o-talets socialism". Tack vare Brasiliens och Argentinas tyngd är det också den enda region där regeringar till vänster om mitten har övertaget och där ojämlikheten minskar - om än från andinska nivåer. Morales, Correas och Chávez "socialism" är ett nytt politiskt fenomen, som betonar sitt oberoende från I900-talets eurasiska modeller för en vänsterpolitik och i sig själv är ytterst heterogen. Den får stöd från många samhällsskikt: fattiga i städerna (sluminvånare, daglönare, gatuförsäljare), ursprungsfolk liksom dem med afrikanskt ursprung, progressiva delar av mellanskikten (akademiker och tjänstemän). Industriarbetarna befinner sig sällan i förtruppen: även om kvarlevorna av Bolivias gruvproletariat anslöt sig till kokaodlarna för att stödja Morales stödde faktiskt Venezuelas största fackförbund den misslyckade kuppen 2002 (Lucena 2007). Mittenvänster-regeringarna på Latinamerikas sydspets har också en varierad social bas, men den traditionella arbetarklassen och dess fackföreningar spelar en mycket större roll och återspeglar Brasiliens och Argentinas högre grad av industrialisering.

De progressiva krafternas ideologi i Latinamerika innehåller många olika strömningar. Chávez inspirerades av Perus militära vänsternationalism och såg i Fidel Castro en viktig läromästare, även om han utvecklade sin egen variant av demokratisk populism och till stor del (om än selektivt) stödde sig på arvet efter Simón Bolívar. Morales är en ledare från Bolivias ursprungsbefolkning, som utvecklade sin förhandlingsskicklighet i kokaodlarnas fackförbund och arbetar jämsides med en veteran från indigenista-rörelsen ${ }^{\mathrm{I} 2}$, vicepresident Álvaro García Linera. Ecuadors Rafael Correa är en utbildad ekonom som påverkats av befrielseteologin, och omges av en grupp begåvade unga tänkare vars uppfattningar sträcker sig från nationalistisk mitten-vänster till marxism.

I2. Indigenismo är en politisk ideologi i Latinamerika som betonar sambandet mellan nationalstaterna och de inhemska ursprungsbefolkningarna. $\mathrm{Nu}$ för tiden syftar det ofta på kampen för att politiskt mobilisera ursprungsfolken. Övers. anm. 
Kretsarna kring Dilma Rousseff, Cristina Fernández de Kirchner och José Mujica står lite till höger om de ovan nämnda, men de är också vidsynta i sitt tänkande. I Mexiko kombinerar rörelsen ledd av Andrés Manuel López Obrador - som vid två tillfällen har besegrats med knapp marginal (eller blivit bortfuskad) som presidentkandidat - republikansk sparsamhet med socialdemokratisk reformism.

Latinamerikas modell kan kanske inte exporteras till resten av världen den närmaste framtiden. Men om det kommer att ske några radikala samhällsomvandlingar de närmaste åren kommer de säkert att ha mer att göra med den senaste utvecklingen i den regionen än med 1900-talets erfarenheter av reformer eller revolution med sin grund i ett lönearbetande proletariat - en samhällsaktör som utgör en mycket liten andel av den arbetande befolkningen i stora delar av Afrika och Asien. ${ }^{13}$ Även om de folkliga klassrörelserna har stärkts tack vare ökande läskunnighet och nya kommunikationssätt ställs de inför stora hinder: splittring längs etniska och religiösa linjer och mellan olika sorters sysselsättning. Men bara de politiska program och organisatoriska former som tar hänsyn till dessa utmaningar kommer att ha en verklig chans att ena dessa underklasskikt.

På lokal nivå kan vi redan återfinna många initiativ av denna typ. De bolivianska kokaodlarna, cocaleros, kunde utnyttja de arbetslösa gruvarbetarnas skicklighet i och erfarenheter av att bygga rörelser. Efter att ha upplevt hur deras medlemmar tvingades bort från formella anställningar har en av fackföreningarna i Maputo organiserat ett förbund för gatuförsäljare (Lindell 20II). Det är inte enda gången detta har hänt: gatuförsäljarna har faktiskt numera sin egen international, StreetNet, med sitt högkvarter i Sydafrika. I Mexico City utgör de en politisk kraft för borgmästaren att räkna med. Indiska kvinnor som arbetar inom den informella ekonomin har byggt upp egna strukturer för ömsesidig hjälp i städer som Mumbai, Chennai och Ahmadabad, och i den nationella SelfEmployed Women's Association (se vidare Bhatt 2005). Fackföreningarna

I3. I Sydasien och Afrika söder om Sahara är endast mellan en femtedel och en fjärdedel av den arbetande befolkningen lönearbetare. I Öst- och Sydöstasien är siffran runt 40 procent och i Latinamerika nästan två tredjedelar, med undantag för Bolivia som sticker ut med långt lägre siffror. Se Therborn 2012, s. 189, tabell 4.5. 
har ofta blivit kanaler för omfattande folkliga protester mot prisökningar och diktatoriska regimer, senast i Tunisien under revolten mot Ben Ali. Arbetare i den formella sektorn har gått i spetsen, men fackliga krav har fått stöd från en bred samling av samhällsrörelser som sträcker sig utanför dessa skikt. Ett exempel är den asiatiska kampanjen för rimliga levnadslöner, "lönegolv", inom konfektionsindustrin, ett transnationellt initiativ som uppstod vid World Social Forum i Mumbai, och fick stöd från fackföreningar, kvinnoorganisationer och icke-statliga utvecklingsorganisationer (Merk 20II). I detta sammanhang blir klass en kompassriktning mot de folkliga klasserna, de exploaterade, förtryckta och missgynnade av alla sorter - snarare än en strukturell kategori som ska fyllas med "medvetenhet". De sociala förbund som framtida omvandlingar kan komma att grunda sig på återstår att skapa, och det går inte att på förhand tilldela någon grupp en "ledande roll". Men utan en klasskompass är det osannolikt att ens de allra bästa sociala rörelser kan övervinna den moderna kapitalismens ojämlikheter.

Följaktligen kan vi för de kommande årtiondena identifiera fyra klassperspektiv som förefaller rimliga i en sociologs ögon: medelklassens globaliserade konsumism, politiskt uppror av medelklassen, industriell klasskamp - vilket kanske ger upphov till nya sociala kompromisser med centrum i Östasien, och brokiga mobiliseringar av de folkliga klasserna. Det nya seklets samhälleliga karaktär är ännu inte avgjord, men klass kommer säkert att vara av central betydelse.

\section{Vänsterns nya geopolitik}

Slutet för den eurocentriska industrisocialismen har långtgående konsekvenser, inte bara för samhällskrafternas sammansättning utan också för hur de organiserar sig. Partiformen - både den tyska socialdemokratins och den italienska kommunismens masspartier och den mindre, leninistiska förtruppen - har förlorat mycket av sin lockelse. Fackföreningar utanför Europa har redan insett sådana partiers begränsningar och försöker förena sig med allehanda sociala rörelser och icke-statliga organisationer. Ändå är en organisatorisk form för politiken fortfarande avgörande för att få politiskt inflytande. 200I års mobiliseringar i Argentina 
fick större inverkan än de spanska indignados ett decennium senare, huvudsakligen därför att det fanns en progressiv politisk mekanism till hands: den peronistiska rörelsens vänsterflygel. Det muslimska brödraskapet med sin orubbliga organisering har visat sig vara den egyptiska revolutionens segrare på medellång sikt. ${ }^{\mathrm{I}}$ Vi ska inte låta oss ryckas med av internets påstått vidsträckta förmåga att mobilisera stöd utanför det politiska livets normala kanaler. ${ }^{\mathrm{Is}}$

Med detta i åtanke har icke desto mindre en mäktig ny dynamik varit uppenbar de senaste åren. Vi har upplevt hur det har uppstått lösa, decentraliserade nätverk, från al-Qaidas franchiseverksamheter och Tea Partyrörelsen till de vänsterorienterade proteströrelserna 20II. "Sjöstjärneliknande" organisationer utan ledare diskuteras nu ivrigt i den moderna företagsledningslitteraturen (Foley 20I2, s. 218). Den "icke-hierarkiska" naturen hos sådana organ är i sig själv varken demokratisk eller progressiv, som exemplen ovan visar. Men kollektiva diskussioner och enskild självbestämmanderätt är utan tvivel ett levande arv från 1968, och måste vara en del av alla framtida vänsterprojekt. Ideologiskt har de nya rörelserna drivits av en blandning av en förkastande hållning ("rejectionism") och av pragmatism. Människor har mobiliserats av ett ilsket förkastande, även om måltavlorna för det har varierat betydligt: upplevda oförskämdheter mot islam har inspirerat protester i många arabiska länder; amorteringslättnader och sjukvårdsförsäkringar för låginkomsttagare, "förlorare”, har väckt Tea Party-anhängarnas vrede; Occupyrörelsen utnyttjade den folkliga ilskan mot räddningsaktioner för bankerna och sjunkande levnadsstandard under en regim av svågerkapitalism. Den förkastande hållningen ger dessa rörelser mod och stridbarhet och skapar en dynamik av konflikter, medan deras pragmatism får dem att undvika dogmatiska gräl och uppvisa en taktisk flexibilitet. Det går ännu inte att se hur vänsterperspektiven kommer att formuleras efter industrisocialismens tidsålder. Men de kommer säkert att omfatta motstånd mot ojämlikhet

I4. För en kommentar om brödraskapets fall och militärens återkomst 20I3, se Therborns andra artikel i detta nummer, "Nya massor? Motståndets sociala grundvalar" (s. IO4). Red. anm.

I5. Manuel Castells viktiga och lägliga studie Networks of Outrage and Hope (2012) är kanske inte helt fri från denna frestelse. 
och imperialistisk arrogans, och vidmakthålla den mänskliga rättigheten att få verka fritt och fullständigt. ${ }^{16}$

Arbetarklassens 1900-tal var till mycket stor del en europeisk skapelse. Den uppstod inom det europeiska familjesystemet, med dess svaga band inom de utvidgade familjerna och relativt oberoende ungdomar, som inte hade några heliga förpliktelser mot sina förfäder och förväntades bilda egna hushåll när de blev vuxna. Det underlättade för en snabb och massiv omvändelse till nya idéer och sociala praktiker. Europas väg till det moderna livet öppnade ett unikt socialt utrymme: de inhemska klasskonflikterna ägde rum inom relativt homogena nationalstater, samtidigt som den etablerade religionen försvagades genom sina band till de besegrade gamla regimerna. Den kapitalistiska utvecklingen skapade en arbetarklass som kunde stödja sig på en omfattande läskunnighet och skråorganisationernas hantverkstraditioner, som varit på plats redan före industrialiseringen. På grund av Europas ledande ställning spreds dess modell för klasspolitik sedan till andra kontinenter - av fattiga utvandrare som reste till Oceanien eller Amerika, av imperiernas informationsoch utbildningskanaler, och inte minst av Sovjetunionens antiimperialistiska motbild. Denna modell för klasspolitik fick hela världen i sitt grepp, men när den inlemmades i de icke-europeiska samhällena förändrades dess innehåll. Arbetarrörelsen var Europas gåva till världen. Den inspirerade mäktiga och uppfinningsrika krafter på varenda kontinent, från Nordamerikas arbetare-bonde-partier till Mariáteguis nyskapande teoretiserande om ursprungsbefolkningen i Peru, från försöken att smida fram en arabisk eller afrikansk socialism till kommunistpartiers mobilisering av bönder i Kina och Vietnam under det nationella oberoendets fana. Som vi sett har detta arv inte suddats ut helt och hållet. Men Europa kan inte längre stå till tjänst med ett internationellt perspektiv på frigörelse, utveckling och rättvisa. För tillfället saknas dessa visioner till och med för kontinenten själv.

I900-talets vänster hade två huvudsakliga inspirationskällor. Den ena fanns i Västeuropa - framför allt i det revolutionära Frankrike och den tyska marxistiska arbetarrörelsen. För världens mest utvecklade och

I6. För en formulering av vad jämlik möjlighet att få verka "fritt och fullständigt" som människa kan innebära, se Sen 1992; Nussbaum 20II; och Therborn 2006. 
mäktiga region representerade den framtiden, och den tillhandahöll idéer och program, organisationsprinciper och modeller för förändring. Den gav också viktigt materiellt stöd: Frankrike stod öppet för radikala landsflyktiga från alla länder, den välorganiserade tyska arbetarrörelsen betalade medlemsavgifter och hjälpte till att finansiera fattigare bröder (Friedrich Ebert-stiftelsen gör det än i dag). Den andra källan fanns i den globala maktens och välståndets periferi, där revolutioner utspelade sig under ledning av politiska strömningar inspirerade av den europeiska marxismen. Sovjetunionen var det första och största av dessa centrum, med Kina och Kuba i kölvattnet. De bistod med modeller för hur man kunde gripa makten och omvandla samhället åt världens alla förhoppningsfulla revolutionärer, för att inte nämna direkt ekonomiskt stöd. För närvarande är Latinamerika - med sina komplicerade sociala strukturer och ideologiska hemmabyggen - det närmaste ett världscentrum vi har i dag. Men det är inte mycket att tala om. 2000-talets vänster kommer troligen stå utan centrum, dessutom är Latinamerika sannolikt en för liten region för att utgöra en global ledstjärna - även om de sociala förändringar som nu är under uppsegling skulle genomföras till sin yttersta gräns. För att en ny vänster ska få en verklig internationell betydelse måste den skaffa sig djupare rötter i Asien.

Vi bevittnar uppkomsten av en ny era: nya klassmässiga och nationella, ideologiska, identitets- och mobiliseringsförhållanden och en ny global vänsterpolitik tar form. Kalla krigets slut gav inte någon "fredsutdelning" utan bara en ny period med krig. Västkapitalismens seger följdes inte av allmänt välstånd utan av ständigt ökande ojämlikhet och återkommande ekonomiska kriser: Östasien, Ryssland, Argentina och nu den pågående europeisk-amerikanska turbulensen. Vänsterns klassiska intressefrågor - kapitalistisk utsugning och imperialism, förtryckande könshierarkier och etnisk diskriminering - har återskapat sig själva under det nya seklet. Kampen kommer att fortsätta, det kan vi vara övertygade om. Men vem kommer att prägla den - den nya medelklassen eller de plebejiska massorna? 


\section{Referenser}

Ashwin, Sarah (2007) "Russian Trade Unions: Stuck in Soviet-Style Subordination?”, i Phelan, Craig (red.) Trade Union Revitalisation, Bern: Peter Lang.

Atkinson, A. B. \& Piketty, Thomas (red.) (20I0) Top Incomes. A Global Perspective, Oxford: Oxford University Press.

Banerjee, Abhijit \& Duflo, Esther (2007) What is Middle Class about Middle Classes around the World?, working paper nr 7-29, MIT Department of Economics.

Banister, Judith (2005) "Manufacturing Employment in China", i Monthly Labor Review, juli.

URL: http://www.bls.gov/opub/mlr/2005/07/art2full.pdf (I november 2014)

Barros, Ricardo Paes de m.fl. (20II) A nova classe média brasileira. Desafios que representa para a formulação de politicas públicas, Brasília: Secretaria de Assuntos Estratégicos.

Beckman, Björn \& Lukman, Salihu (20I0) "The Failure of Nigeria's Labour Party", i Beckman, Björn, Buhlungu, Sakhela \& Sachikonye, Lloyd (red.) Trade Unions and Party Politics, Kapstaden: HSRC Press.

Berg, Janine (20II) "Laws or Luck? Understanding Rising Formality in Brazil in the 200os", i Lee, Sangheon \& McCann, Deirdre (red.) Regulating for Decent Work, Basingstoke: Palgrave Macmillan.

Bhatt, Ela R. (2005) We Are Poor but so Many, New York: Oxford University Press.

Birdsall, Nancy (20IO) The (Indispensable) Middle Class in Developing Countries, working paper 207, Washington: Center for Global Development.

Bourne, Richard (2008) Lula of Brazil, London: Zed Books.

Breman, Jan (2010) Outcast Labour in Asia, Oxford: Oxford University Press.

Castells, Manuel (2012) Networks of Outrage and Hope, Cambridge: Polity.

CEPAL (2010) La hora de la igualdad, Santiago: Comisión Económica para América Latina. URL: http://www.cepal.org/publicaciones/xml/o/397Io/IOo604_20IO-II4-ses.33-3_ la_hora_de_la_igualdad_doc_completo.pdf (I november 20I4)

Cheng, Joseph Y. S., Ngok, Kinglun \& Zhuang, Wenjia (2010) "The Survival and Development Space for China's Labor NGOs: Informal Politics and Its Uncertainty", i Asian Survey, volym 50, nr 6.

DoI: http://dx.doi.org/I0.1525/as.2010.50.6.1082

Chunling, Li (20I2) "Profile of China's Middle Class", i Chunling, Li (red.) The Rising Middle Classes in China, Milton Keynes: Paths International.

Cooke, Fang Lee (20II) "The Enactment of Three New Labour Laws in China: Unintended Consequences and the Emergence of 'New' Actors in Employment Relations", i Lee, Sangheon \& McCann, Deirdre (red.) Regulating for Decent Work, Basingstoke: Palgrave Macmillan.

Cornia, Giovanni Andrea \& Martorano, Bruno (2010) Policies for reducing income inequality: Latin America during the last decade, working paper, New York: UNICEF.

Davis, Diane E. (2004) Discipline and Development, Cambridge: Cambridge UP.

Fernandes, Leela (2006) India's New Middle Class, Minneapolis: University of Minnesota Press. 
Ferus-Comelo, Anibel (2007) "Unions in India at Critical Crossroads", i Phelan, Craig (red.) Trade Union Revitalisation, Bern: Peter Lang.

FN (20II) The Millennium Development Goals Report 20II, New York: Förenta Nationerna. URL: http://www.un.org/millenniumgoals/pdf/\%2820II_E\%29\%20MDG\%20 Report\%2O2OII_Book\%2OLR.pdf (I november 20I4)

Foley, Elizabeth Price (2012) The Tea Party. Three Principles, Cambridge: Cambridge University Press.

Ford, Michele (2007) "Indonesia's New Unions", i Phelan, Craig (red.) Trade Union Revitalisation, Bern: Peter Lang.

Grimm, Michael m.fl. (20I0) "Inequality in Human Development: An Empirical Assessment of 32 Countries", i Social Indicators Research, volym 97, nr 2. DOI: http://dx.doi.org/I0.I007/sII205-009-9497-7

Hobsbawm, Eric (1978) "The Forward March of Labour Halted?", i Marxism Today, volym $22, \mathrm{nr} 9$.

Hsiao, Hsin-Huang M. (2006) "Prioritizing the Middle Classes: Research in Asia-Pacific", i Hsiao, Hsin-Huang M. (red.) The Changing Faces of Middle Classes in AsiaPacific, Taipei: Center for Asia-Pacific Area Studies.

IHT (200I) "Top I\% increase share of US income", International Herald Tribune, 27 oktober.

IMF (2007) World Economic Outlook 2007, New York: Internationella valutafonden.

Jaffrelot, Christophe (2008) "'Why Should We Vote?' The Indian Middle Class and the Functioning of the World's Largest Democracy", i Jaffrelot, Christophe \& Veer, Peter van der (red.) Patterns of Middle Class Consumption in India and China, New Delhi: SAGE.

Jin, He (20I2) "The Transformation and Power of 'Middle Class' Language in Chinese Media Publications", i Chunling, Li (red.) The Rising Middle Classes in China, Milton Keynes: Paths International.

Jones, Owen (201I) Chavs. The Demonization of the Working Class, London: Verso.

Jünger, Ernst (1982 [1932]) Der Arbeiter. Herrschaft und Gestalt, Stuttgart: Klett-Cotta.

Kandil, Hazem (20I2) "Why Did the Egyptian Middle Class March to Tahrir Square?", i Mediterranean Politics, volym $17, \mathrm{nr} 2$. DoI: http://dx.doi.org/IO.IO80/13629395.20I2.694044

Krugman, Paul (20II) "Oligarchy, American style", International Herald Tribune, 5 november.

Leahy, Joe (20I2) "FT Interview: Dilma Rousseff", Financial Times, 3 oktober.

Lee, Yoonkyung (20II) Militants or Partisans. Labor Unions and Democratic Politics in Korea and Taiwan, Stanford: Stanford University Press.

Leeuwen, Lizzy van (20II) Lost in Mall, Leiden: KITLV Press.

Lindell, Ilda (20II) "Informal Work and Transnational Organizing", i Bieler, Andreas \& Lindberg, Ingemar (red.) Global Restructuring, Labour, and the Challenges for Transnational Solidarity, Abingdon: Routledge.

Lowrey, Annie (2012) "Wealth disparity a drag on economic growth", International Herald Tribune, 17 oktober. 
Lucena, Héctor (2007) "Trade Unionism in Venezuela: The Current Situation", i Phelan, Craig (red.) Trade Union Revitalisation, Bern: Peter Lang.

Mason, Paul (20I2) Why It's Kicking Off Everywhere, London: Verso.

Merk, Jeroen (20II) "Cross-Border Wage Struggles in the Global Garment Industry: The Campaign for an Asia Floor Wage", i Bieler, Andreas \& Lindberg, Ingemar (red.) Global Restructuring, Labour, and the Challenges for Transnational Solidarity, Abingdon: Routledge.

Milanovic, Branko (20II) The Haves and the Have-Nots, New York: Basic Books.

Milanovic, Branko (2OI2) "Global Inequality Recalculated and Updated", i Journal of Economic Inequality, volym Io, $\mathrm{nr}$. Dor: http://dx.doi.org/I0.1007/sio888-0I0-9155-y

Nussbaum, Martha C. (20II) Creating Capabilities. The Human Development Approach, Cambridge: Harvard University Press.

OECD (2007) OECD Employment Outlook 2007, Paris: OECD.

OECD (20II) Perspectives of Global Development 20I2, Paris: OECD.

Ravallion, Martin (20I0) "The Developing World's Bulging (but Vulnerable) Middle Class", World Development, volym 38, nr 4.

Dor: http://dx.doi.org/ı.Ior6/j.worlddev.2009.II.007

Rocca, Jean-Louis (2012) "Political Crossroad, Social Representations and Academic Intervention: The Formation of a Middle Class in China”, i Chunling, Li (red.) The Rising Middle Classes in China, Milton Keynes: Paths International.

Sen, Amartya (1992) Inequality Reexamined, Oxford: Clarendon Press.

Sen, Sukomal (1997) Working Class of India, 2 utökade uppl., Calcutta: K.P. Bagchi \& Co.

Shi, Li (2008) Rural Migrant Workers in China: Scenario, Challenges and Public Policy, working paper nr 89, Genève: ILO Policy Integration and Statistics Department.

Skocpol, Theda \& Williamson, Vanessa (2012) The Tea Party and the Remaking of Republican Conservatism, New York: Oxford University Press.

So, Alvin (2006) "Historical Formation, Transformation, and the Future Trajectory of Middle Classes in Asia”, i Hsiao, Hsin-Huang M. (red.) The Changing Faces of Middle Classes in Asia-Pacific, Taipei: Center for Asia-Pacific Area Studies.

Therborn, Göran (1977) "The Rule of Capital and the Rise of Democracy", i New Left Review, nr I03 (äldre följd).

Therborn, Göran (1984) "The Prospects of Labour and the Transformation of Advanced Capitalism", i New Left Review, nr I45 (äldre följd).

Therborn, Göran (2006) "Meaning, Mechanisms, Patterns, and Forces: An Introduction", i Therborn, Göran (red.) Inequalities of the World, London: Verso.

Therborn, Göran (2012) Världen. En inledning, Malmö: Liber.

UNDP (2010) Regional Human Development Report for Latin America and the Caribbean 20I0, New York: FN:s utvecklingsprogram.

URL: http://www.undp.org/content/dam/undp/library/corporate/HDR/Latin\%20 America\%20and\%20Caribbean\%2oHDR/rhdr_lac_en_20Io.pdf (I november 20I4)

UN-HABITAT (2008) The State of the World's Cities 2008/2009, London: United Nations Human Settlements Programme. 
Varma, Pavan K. (1998) The Great Indian Middle Class, New Delhi: Viking.

Xin, Liu (2012) "Urban Chinese Class Structure and the Direction of the Middle Class", i Chunling, Li (red.) The Rising Middle Classes in China, Milton Keynes: Paths International.

Zhou, Xiaohong (2008) "Chinese Middle Class: Reality or Illusion?", i Jaffrelot, Christophe \& Veer, Peter van der (red.) Patterns of Middle Class Consumption in India and China, New Delhi: SAGE.

Zhou, Xiaohong \& Chen, Qin (20I2) "Globalization, Social Transformation and Construction of the Chinese Middle Classes", i Chunling, Li (red.) The Rising Middle Classes in China, Milton Keynes: Paths International. 


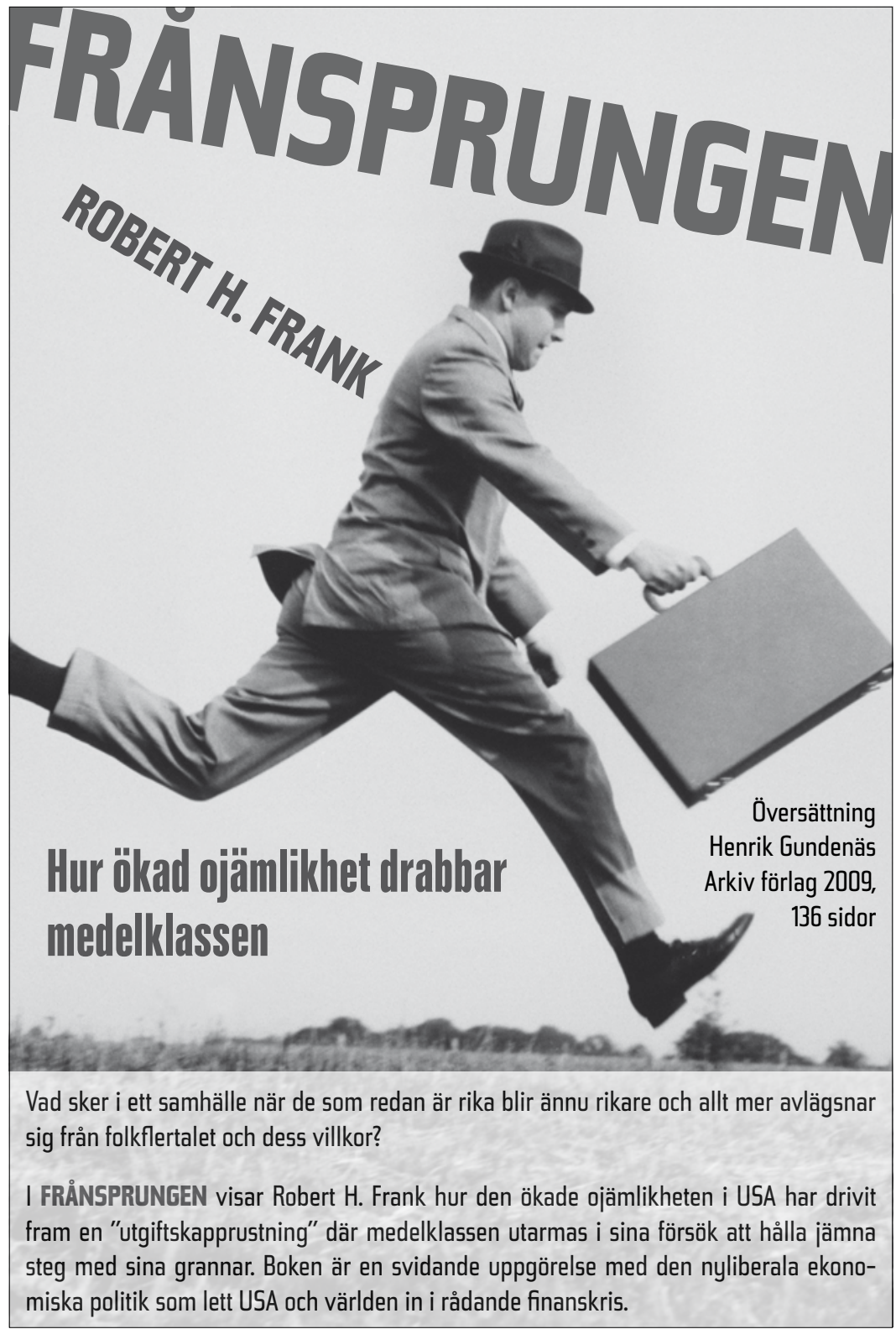

»Läs mer om boken på www.arkiv.nu巛 